\title{
Evaluation of presynchronized resynchronization protocols for lactating dairy cows
}

\author{
R. C. Chebel, ${ }^{\star 1}$ A. A. Scanavez, ${ }^{*}$ P. R. B. Silva, ${ }^{*}$ J. G. N. Moraes, ${ }^{*}$ L. G. D. Mendonça, ${ }^{*}$ and G. Lopes Jr.† \\ ${ }^{*}$ Department of Veterinary Population Medicine, University of Minnesota, Saint Paul 55108 \\ †Accelerated Genetics, Baraboo, WI 53913
}

\begin{abstract}
The objectives of this experiment were to determine the speed at which cows that had their estrous cycle presynchronized with a $\mathrm{GnRH}$ or $\mathrm{PGF}_{2 \alpha}$ injection are reinseminated and become pregnant. Furthermore, this experiment aimed to determine whether treatment with a controlled internal drug-releasing (CIDR) insert during the timed artificial insemination (AI) protocol improves pregnancy per AI (P/AI) of cows that had their estrous cycle presynchronized with GnRH or $\mathrm{PGF}_{2 \alpha}$. Lactating cows from 2 herds were assigned to 1 of 2 presynchronization treatments at $32 \pm 4 \mathrm{~d}$ after AI: GGPG $(\mathrm{n}=452)-\mathrm{GnRH}$ injection at enrollment (d 0), $7 \mathrm{~d}$ before the start of the timed AI protocol, and P11GPG $(\mathrm{n}=466)-\mathrm{PGF}_{2 \alpha}$ injection on $\mathrm{d} 3,11$ $\mathrm{d}$ before the start of the timed AI protocol. Cows observed in estrus at any interval after enrollment were reinseminated on the same day. Cows not observed in estrus by $\mathrm{d} 7$ were paired by presynchronization treatment and assigned to receive or not receive a CIDR insert during the timed AI protocol (CIDR $=240$, no CIDR $=317$ ). Timed AI protocols were the Ovsynch56 at site $\mathrm{A}$ and the Cosynch 48 at site B. A subsample of cows from site A had their ovaries scanned by ultrasound at enrollment and on the day of the first $\mathrm{GnRH}$ and $\mathrm{PGF}_{2 \alpha}$ injections of the timed AI protocol and had blood sampled at each injection of the timed AI protocol for determination of progesterone concentration. Cows were examined for pregnancy $32 \pm 4$ and $67 \pm 4 \mathrm{~d}$ after reinsemination. Cows in the P11GPG treatment had a faster reinsemination rate [adjusted hazard ratio $=1.24$ $(95 \% \mathrm{CI}=1.07,1.45)]$ and were less likely to be submitted to the timed AI protocol (40.3 vs. $89.8 \%$ ) and to be reinseminated at a fixed time (38.6 vs. $83.9 \%$ ). The interval from enrollment to reinsemination was shorter for cows in the P11GPG group $(13.0 \pm 0.4$ vs. $15.0 \pm$ $0.2 \mathrm{~d})$. Presynchronization treatment did not affect $\mathrm{P} /$ $\mathrm{AI} 32 \pm 4 \mathrm{~d}(\mathrm{GGPG}=42.3 \%, \mathrm{P} 11 \mathrm{GPG}=39.3 \%)$ and
\end{abstract}

Received June 29, 2012.

Accepted October 7, 2012.

${ }^{1}$ Corresponding author: chebe002@umn.edu
$67 \pm 4 \mathrm{~d}(\mathrm{GGPG}=37.0 \%, \mathrm{P} 11 \mathrm{GPG}=35.4 \%)$ after reinsemination. Pregnancy rate from d 0 to 7 (GGPG $=3.6 \%, \mathrm{P} 11 \mathrm{GPG}=17.7 \%)$ and from $\mathrm{d} 8$ to $14(\mathrm{GGPG}$ $=1.6 \%, \mathrm{P} 11 \mathrm{GPG}=5.7 \%$ ) were greater for cows in the P11GPG treatment. Treatment with the CIDR insert during the timed AI protocol did not affect $\mathrm{P} / \mathrm{AI} 32$ $\pm 4 \mathrm{~d}(\mathrm{CIDR}=41.7 \%$, no $\mathrm{CIDR}=41.4 \%)$ and $67 \pm$ $4 \mathrm{~d}(\mathrm{CIDR}=36.5 \%$, no $\mathrm{CIDR}=35.3 \%)$ after reinsemination. A greater percentage of cows in the GGPG treatment had progesterone concentration $\geq 1 \mathrm{ng} / \mathrm{mL}$ on the day of the first GnRH injection of the timed AI protocol (83.8 vs. 51.5\%), but a greater percentage of cows in the P11GPG treatment ovulated in response to the first GnRH injection of the timed AI protocol (66.1 vs. $46.8 \%$ ). We conclude that the P/AI of cows that had their estrous cycle presynchronized with $\mathrm{GnRH}$ or $\mathrm{PGF}_{2 \alpha}$ was not different, but in herds with adequate estrous detection efficiency and accuracy, presynchronization with $\mathrm{PGF}_{2 \alpha}$ may reduce the interval to the establishment of pregnancy.

Key words: presynchronization, resynchronization, controlled internal drug-releasing insert, lactating dairy cow

\section{INTRODUCTION}

Several protocols for resynchronization of the estrous cycle of nonpregnant cows have been developed and evaluated since the development of timed AI protocols in the 1990s (Pursley et al., 1995). In general, resynchronization protocols must result in acceptable pregnancy per AI (P/AI) and timely reinsemination of cows to avoid an extended inter-AI interval. Because many dairy herds have inadequate estrous detection rates, timed AI protocols are often recommended for reinsemination of lactating dairy cows.

In recent studies, presynchronization of the estrous cycle of nonpregnant cows with $\mathrm{PGF}_{2 \alpha} 12 \mathrm{~d}$ before the start of the timed AI protocol (Silva et al., 2007) and with GnRH $7 \mathrm{~d}$ before the start of the timed AI protocol (Dewey et al., 2010) improved P/AI after reinsemination. In the experiment in which $\mathrm{PGF}_{2 \alpha}$ was used to presynchronize the estrous cycle, however, cows 
were not reinseminated if detected in estrus, and all cows were submitted to the timed AI protocol, thereby extending the interval between inseminations by approximately $12 \mathrm{~d}$ compared with nonpresynchronized cows (Silva et al., 2007). On the other hand, in the experiment in which GnRH was used to presynchronize the estrous cycle, cows were allowed to be reinseminated if detected in estrus (Dewey et al., 2010), but $\mathrm{GnRH}$ reduced the percentage of cows observed in estrus and increased the interval to reinsemination by approximately $2 \mathrm{~d}$ (Mendonça et al., 2011). The comparison of estrous cycle presynchronization protocols using GnRH or $\mathrm{PGF}_{2 \alpha}$ injections in herds that also rely on estrous detection for reinsemination of nonpregnant cows is important because of the different effects of GnRH and $\mathrm{PGF}_{2 \alpha}$ on estrous expression (Chebel et al., 2006; Mendonça et al., 2011).

Treatment of cows with controlled internal drugreleasing (CIDR) inserts during resynchronization protocols improves $\mathrm{P} / \mathrm{AI}$ to reinsemination by approximately 5 percentage units when the resynchronization protocols are initiated at approximately $38 \pm 3 \mathrm{~d}$ after AI (Dewey et al., 2010; Bilby et al., 2011). It is not clear, however, whether the use of a CIDR insert during a resynchronization protocol would increase $\mathrm{P} / \mathrm{AI}$ to reinsemination of cows that had their estrous cycle presynchronized with $\mathrm{GnRH}$ or $\mathrm{PGF}_{2 \alpha}$.

The hypothesis of the current experiment was that cows that had the estrous cycle presynchronized with $\mathrm{PGF}_{2 \alpha}$ would be reinseminated at a faster rate and would therefore have greater pregnancy rates before being submitted to the timed AI protocol than would cows that had their estrous cycle presynchronized with GnRH. Furthermore, it was hypothesized that cows submitted to a timed AI protocol and treated with a CIDR insert would have greater P/AI than cows submitted to a timed AI protocol and not treated with a CIDR insert.

The objectives of the current experiment were to (1) determine the speed at which cows that were not pregnant to a previous AI and that had their estrous cycle presynchronized with a $\mathrm{GnRH}$ or $\mathrm{PGF}_{2 \alpha}$ injection were reinseminated and would become pregnant, and (2) determine whether treatment with a CIDR insert during the timed AI protocol of cows that had their estrous cycle presynchronized with $\mathrm{GnRH}$ or $\mathrm{PGF}_{2 \alpha}$ would improve P/AI.

\section{MATERIALS AND METHODS}

\section{Cows, Nutrition, and Facilities}

Lactating Jersey (site A, $\mathrm{n}=611$ ) and Holstein (site $\mathrm{B}, \mathrm{n}=307$ ) cows that had previously been inseminated were enrolled in the experiment $32 \pm 4 \mathrm{~d}$ after the previous AI (day of enrollment $=\mathrm{d} 0$ ). Sites A and B were cross-ventilated freestall barns. Site A was located in Nicollet, Minnesota $\left(44^{\circ} 16^{\prime} 25^{\prime \prime} \mathrm{N} 94^{\circ} 11^{\prime} 18^{\prime \prime} \mathrm{W}\right)$, and site B was located in Rice Lake, Wisconsin $\left(45^{\circ} 29^{\prime} 54^{\prime \prime} \mathrm{N}\right.$ $\left.91^{\circ} 44^{\prime} 20^{\prime \prime} \mathrm{W}\right)$. At site A, cows were fed a TMR twice daily, and at site B, cows were fed a TMR once daily. The main ingredients in the TMR at both sites were corn silage, alfalfa hay, corn meal, soybean meal, cottonseed, and a mineral and vitamin premix. At both sites, first-lactation and mature cows were kept separate throughout their lactation. The experiment was conducted from May to September at site A and from October to December at site B.

\section{Treatments}

Cows were assigned randomly to a presynchronization treatment $(\mathrm{GGPG}=452$ or $\mathrm{P} 11 \mathrm{GPG}=466)$ at enrollment ( $\mathrm{d} 0$ ). Cows enrolled in the GGPG treatment received a presynchronizing injection of $\mathrm{GnRH}$ (100 $\mu \mathrm{g}$ of gonadorelin hydrocloride; Factrel, Pfizer Animal Health, Madison, NJ) on d 0 and, if not observed in estrus and reinseminated, they were enrolled in the timed AI protocol on d 7 (Figure 1). Cows enrolled in the P11GPG treatment diagnosed as not pregnant 32 $\pm 4 \mathrm{~d}$ after a previous AI received a presynchronizing injection of $\mathrm{PGF}_{2 \alpha}$ (25 mg of dinoprost tromethamine; Lutalyse, Pfizer Animal Health) on d 3 and were observed for estrus, and if not observed in estrus and reinseminated, they were enrolled in the timed AI protocol on d 11 (Figure 1).

Cows enrolled in the GGPG and P11GPG treatments that were submitted to the timed AI protocol were assigned randomly to receive $(\mathrm{n}=240)$ or not receive $(\mathrm{n}=317)$ a CIDR insert [1.38 $\mathrm{g}$ of progesterone (P4), Eazi-Breed CIDR; Pfizer Animal Health] from the first $\mathrm{GnRH}$ injection to the $\mathrm{PGF}_{2 \alpha}$ injection of the timed AI protocol. The timed AI protocol to which cows were submitted were the Ovsynch56 (GnRH, 7 d later $\mathrm{PGF}_{2 \alpha}, 56 \mathrm{~h}$ later $\mathrm{GnRH}$, and 12 to $16 \mathrm{~h}$ later fixed-time AI) at site $\mathrm{A}$ and the Cosynch48 ( $\mathrm{GnRH}, 7$ $\mathrm{d}$ later $\mathrm{PGF}_{2 \alpha}, 48 \mathrm{~h}$ later $\mathrm{GnRH}$ and fixed-time $\mathrm{AI}$ ) at site B.

\section{Estrous Detection and Al}

At site A, estrous detection was primarily performed by tail paint removal, and at site $\mathrm{B}$, estrous detection was primarily performed by pedometers (Afimilk; S.A.E. Afikim, Kibbutz Afikim, Israel). Furthermore, in both herds, the following symptoms were used to characterize estrus: vaginal mucous discharge, bellowing, increased nervousness and activity, walking the 
Site A

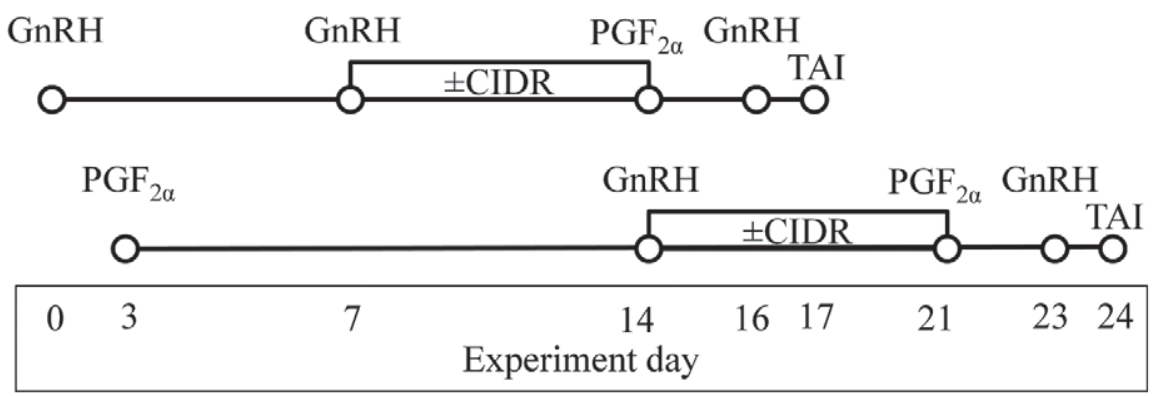

Site B

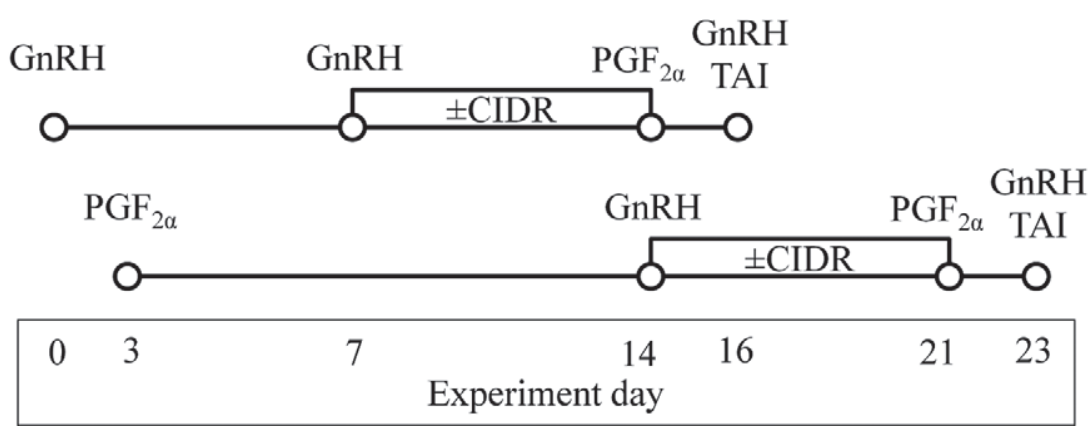

Figure 1. Schematic representation of resynchronization protocols used in the current experiment. Presynchronization treatments: GGPG $=$ presynchronizing injection of $\mathrm{GnRH}(100 \mu \mathrm{g}$ of gonadorelin hydrocloride; Factrel, Pfizer Animal Health, Madison, NJ) on d 0 (day of enrollment) and submission to the timed $\mathrm{AI}$ (TAI) protocol on $\mathrm{d} 7$ if not observed in estrus; P11GPG $=$ presynchronizing injection of PGF ${ }_{2 \alpha}$ (25 $\mathrm{mg}$ of dinoprost tromethamine; Lutalyse, Pfizer Animal Health) on d 3 and submission to the TAI protocol on d 11 if not observed in estrus. Cows submitted to the TAI protocol were assigned randomly to receive or not receive a controlled internal drug-releasing (CIDR) insert (1.38 $\mathrm{g}$ of progesterone, Eazi-Breed CIDR; Pfizer Animal Health) from the first GnRH injection to the PGF ${ }_{2 \alpha}$ injection of the TAI protocol. Timed AI protocols were the Ovsynch56 (GnRH, 7 d later $\mathrm{PGF}_{2 \alpha}, 56 \mathrm{~h}$ later $\mathrm{GnRH}$, and 12 to $16 \mathrm{~h}$ later fixed-time $\left.\mathrm{AI}\right)$ at site $\mathrm{A}$ and the Cosynch48 (GnRH, 7 d later $\mathrm{PGF}_{2 \alpha}, 48 \mathrm{~h}$ later $\mathrm{GnRH}$, and fixed-time $\mathrm{AI}$ ) at site $\mathrm{B}$.

fence line, swelling and reddening of the vulva, mounting other cows, or standing estrus. At sites A and B, cows were inseminated once daily in the morning by 1 of 3 technicians who were randomly distributed across treatments. Cows inseminated in estrus after the $\mathrm{PGF}_{2 \alpha}$ injection of the timed AI protocol were considered to have completed the timed AI protocol.

\section{BCS and Milk Yield}

Cows received a BCS $(1=$ emaciated, $5=$ obese $)$ on experiment d 0. Milk yields were recorded for individual cows once monthly, and projected 305-d milk yield was used for statistical analysis.

\section{Ultrasonography of Ovaries and Blood Samples}

At site A, ovaries of 342 cows (GGPG $=166$, P11G$\mathrm{PG}=176)$ were examined by ultrasound $(5-\mathrm{MHz}$ linear probe, Ibex Lite; EI Medical Imagin, Loveland, CO) at nonpregnancy diagnosis for diagnosis of a corpus luteum (CL) and follicles $\geq 10 \mathrm{~mm}$ in diameter. Furthermore, 216 cows $(\mathrm{GGPG}=155, \mathrm{P} 11 \mathrm{GPG}=61)$ enrolled in the timed AI protocol had their ovaries examined at the time of the first GnRH injection and at the time of the $\mathrm{PGF}_{2 \alpha}$ injection of the timed $\mathrm{AI}$ protocol for diagnosis of a CL and follicles $\geq 10 \mathrm{~mm}$ in diameter. Cows were considered to have ovulated in response to the first GnRH injection of the timed AI protocol if they had a follicle $\geq 10 \mathrm{~mm}$ in diameter on the day of the first GnRH injection and a newly formed CL in the same ovary $7 \mathrm{~d}$ later.

At site A, blood samples for determination of $\mathrm{P} 4$ concentration were collected at the time of the first GnRH injection of the timed AI protocol (GGPG = $173, \mathrm{P} 11 \mathrm{GPG}=66)$, at the time of the $\mathrm{PGF}_{2 \alpha}$ injection of the timed AI protocol $(\mathrm{GGPG}=155, \mathrm{P} 11 \mathrm{GPG}=$ $62)$, and at fixed-time AI (GGPG $=152, \mathrm{P} 11 \mathrm{GPG}=$ 62 ). On the day of the $\mathrm{PGF}_{2 \alpha}$ injection, blood samples were collected 20 min after removal of the CIDR insert 
to avoid confounding from exogenous P4 (Cerri et al., 2009a). Cows were classified as having P4 concentration $<1$ or $\mathrm{P} 4$ concentration $\geq 1 \mathrm{ng} / \mathrm{mL}$ at the time of the $\mathrm{GnRH}$ and $\mathrm{PGF}_{2 \alpha}$ injections of the fixed-time $\mathrm{AI}$ and $\mathrm{P} 4<1 \mathrm{ng} / \mathrm{mL}$ at fixed-time AI. Cows were considered to have had their estrous cycle synchronized when $\mathrm{P} 4$ concentration at the time of $\mathrm{PGF}_{2 \alpha}$ was $\geq 1 \mathrm{ng} / \mathrm{mL}$ and $\mathrm{P} 4$ concentration at fixed-time AI was $<1 \mathrm{ng} / \mathrm{mL}$.

\section{Pregnancy Diagnosis}

At site A, cows were examined by ultrasonography (5 MHz linear probe; Ibex Lite; EI Medical Imagin, Loveland, CO) at $31 \pm 3 \mathrm{~d}$ after AI. Pregnancy was characterized by the presence of fluid, an embryo, and a heartbeat. Cows diagnosed as pregnant were reexamined 5 wk later, $66 \pm 3 \mathrm{~d}$ after AI. At site B, cows were diagnosed for pregnancy based on serum concentration of pregnancy-specific protein B (BioTracking LLC, Moscow, ID) at $33 \pm 3 \mathrm{~d}$ after AI. Cows diagnosed pregnant were reexamined 5 wk later, at $68 \pm 3 \mathrm{~d}$ after AI.

\section{Calculation of Reproductive Outcomes}

The interval from enrollment to reinsemination, percentage of cows submitted to the timed AI protocol, and percentage of cows reinseminated at a fixed time (reinsemination after the $\mathrm{PGF}_{2 \alpha}$ injection of the timed AI protocol) were calculated for each treatment. Pregnancy per AI of cows reinseminated in estrus, $\mathrm{P} / \mathrm{AI}$ of cows reinseminated at a fixed time (after the $\mathrm{PGF}_{2 \alpha}$ injection of the timed AI protocol), and overall (cows reinseminated in estrus and at a fixed time) P/AI were calculated.

Furthermore, we calculated the percentage of cows that became pregnant from d 0 to 7 and from d 8 to 14 . Percentages of cows that became pregnant within these periods were calculated by dividing the number of cows that became pregnant between $\mathrm{d} 0$ and 7 and between d 8 and 14 by the number of nonpregnant cows in each treatment within each interval.

\section{Statistical Analysis}

The experiment was completely randomized, with cows blocked according to parity. A paper list was created in which treatments were determined randomly by using a coin toss. Individual numerical identification of cows was then written on the paper list sequentially as cows were found in the pen. Cows not reinseminated in estrus before d 7 were assigned randomly to receive or not receive a CIDR insert by using a coin toss after being paired by presynchronization treatment.
A sample size of 450 experimental units per presynchronization treatment (GGPG vs. P11GPG) was expected to provide enough replicates to detect statistical significance with a 6 percentage unit difference in $\mathrm{P} /$ $\mathrm{AI}$ at $67 \pm 4 \mathrm{~d}$ after reinsemination, when $\mathrm{P} / \mathrm{AI}$ ranges from 25 to $35 \%$ ( $\alpha=0.05 ; \beta=0.20$; one-tailed test). In addition, we expected that approximately 400 cows would be enrolled in the timed AI protocol, resulting in 200 cows receiving a CIDR insert and 200 cows not receiving a CIDR insert during the timed AI protocol. Therefore, a sample size of 200 cows per CIDR treatment (CIDR vs. no CIDR) was expected to provide enough replicates to detect statistical significance with a 9 percentage unit difference in $\mathrm{P} / \mathrm{AI}$ at $67 \pm 4 \mathrm{~d}$ after reinsemination, when $\mathrm{P} / \mathrm{AI}$ ranges from 25 to $35 \%$ ( $\alpha$ $=0.05 ; \beta=0.20$; one-tailed test).

Data from all cows or only from cows that were enrolled in the timed AI protocol were used for the statistical analysis. The GLIMMIX procedure of SAS (version 9.2, SAS/STAT; SAS Institute Inc., Cary, NC) was used to analyze dichotomous outcomes by logistic regression using the "binary" distribution function and continuous outcomes by ANOVA. Fixed effects included in the models were presynchronization treatment (GGPG vs. P11GPG), CIDR treatment (yes vs. no), parity (primiparous vs. multiparous), BCS, DIM at enrollment, and reinsemination type (estrus vs. fixed-time AI). Fixed effects with a $P$-value $>0.10$ were removed in a stepwise backward elimination process until only fixed effects with a $P$-value $\leq 0.10$ remained in the model. Presynchronization treatment, CIDR treatment, and parity were forced in all models. Site was included in the model as a random effect, and cows were nested within site.

The rate at which cows were reinseminated was analyzed by the Cox proportional hazard ratio using the PHREG procedure of SAS, with removal of variables by a stepwise backward elimination process based on the Wald statistic criterion when $P>0.10$. Survival analysis, using the LIFETEST procedure of SAS, was used to analyze the interval from enrollment to reinsemination. Statistical significance was defined as $P \leq$ 0.05 and statistical tendencies as $0.05<P \leq 0.10$.

\section{RESULTS}

Table 1 depicts the comparison between presynchronization treatments regarding lactation number, days since previous insemination at enrollment, DIM at enrollment, number of previous inseminations at enrollment, BCS at enrollment, and projected 305-d milk yield. Cows in the GGPG treatment had $(P=0.04)$ reduced DIM compared with cows in the P11GPG group, and cows in the GGPG group tended to have a 
Table 1. Comparison of lactation number, days since previous insemination, DIM, number of inseminations, $\mathrm{BCS}$, and projected 305-d milk yield between presynchronization treatments (mean $\pm \mathrm{SEM})^{1}$

\begin{tabular}{lccc}
\hline Item & GGPG & P11GPG & $P$-value \\
\hline Number of cows & 452 & 466 & - \\
Lactation number & $2.2 \pm 0.6$ & $2.2 \pm 0.6$ & 0.89 \\
Days since previous insemination & $32.4 \pm 0.1$ & $32.5 \pm 0.1$ & 0.45 \\
DIM & $160.3 \pm 3.2$ & $169.5 \pm 3.2$ & 0.04 \\
Number of inseminations & $2.4 \pm 0.1$ & $2.6 \pm 0.1$ & 0.07 \\
BCS & $2.76 \pm 0.1$ & $2.81 \pm 0.1$ & 0.09 \\
Projected 305-d milk yield, kg & $11,129.7 \pm 91.1$ & $11,041.3 \pm 90.9$ & 0.48 \\
\hline
\end{tabular}

${ }^{1}$ Presynchronization treatments: GGPG = presynchronizing injection of GnRH (100 $\mu \mathrm{g}$ of gonadorelin hydrocloride; Factrel, Pfizer Animal Health, Madison, NJ) on d 0 (day of enrollment) and submission to the timed AI protocol on $\mathrm{d} 7$ if not observed in estrus; P11GPG = presynchronizing injection of $\mathrm{PGF}_{2 \alpha}$ (25 mg of dinoprost tromethamine; Lutalyse, Pfizer Animal Health) on d 3 and submission to the timed AI protocol on d 11 if not observed in estrus. Cows submitted to the timed AI protocol were assigned randomly to receive or not receive a CIDR insert (1.38 $\mathrm{g}$ of $\mathrm{P}_{4}$; Eazi-Breed CIDR, Pfizer Animal Health) from the first GnRH injection to the $\mathrm{PGF}_{2 \alpha}$ injection of the timed AI protocol. Timed AI protocols were the Ovsynch56 (GnRH, $7 \mathrm{~d}$ later PGF $\mathrm{P}_{2 \alpha}$, $56 \mathrm{~h}$ later $\mathrm{GnRH}$, and 12 to $16 \mathrm{~h}$ later fixed time $\mathrm{AI}$ ) in site $\mathrm{A}$ and the Cosynch48 (GnRH, $7 \mathrm{~d}$ later $\mathrm{PGF}_{2 \alpha}$, $48 \mathrm{~h}$ later $\mathrm{GnRH}$ and fixed time $\mathrm{AI})$ in site B.

reduced number of inseminations $(P=0.07)$ and lower BCS $(P=0.09)$ at enrollment compared with cows in the P11GPG group (Table 1).

\section{Pattern of Reinsemination}

According to the Cox proportional hazard ratio model, cows in the P11GPG group were reinseminated at a faster $(P<0.01)$ rate than cows in the GGPG group (Table 2). Thus, a greater $(P<0.01)$ percentage of cows in the GGPG group were submitted to the timed AI protocol compared with those in the P11GPG protocol (Table 2). Furthermore, the percentage of cows in the GGPG group reinseminated at a fixed time was greater than $(P<0.01)$ the percentage of cows in the P11GPG group reinseminated at a fixed time (Table 2). Consequently, the interval from enrollment to reinsemination was greater $(P<0.01)$ for cows in the GGPG group compared with cows in the P11GPG group, despite the 7-d delay to the resynchronized timed AI (Table 2 and Figure 2).

\section{Pregnancy per Insemination and Pregnancy Rates of All Cows}

Percentage of cows pregnant $32 \pm 4 \mathrm{~d}$ after reinsemination was not $(P=0.43)$ affected by presynchronization treatment (Table 2). Cows reinseminated in estrus $(38.1 \%)$ and at a fixed time $(42.5 \%)$ had similar $(P=0.23) \mathrm{P} / \mathrm{AI} 32 \pm 4 \mathrm{~d}$ after reinsemination. The interaction between presynchronization treatment and reinsemination type did not $(P=0.82)$ affect $\mathrm{P} / \mathrm{AI}$ $32 \pm 4 \mathrm{~d}$ after reinsemination (Figure 3). Similarly, presynchronization treatment $(P=0.70)$ did not affect $\mathrm{P} / \mathrm{AI} 67 \pm 4 \mathrm{~d}$ after reinsemination (Table 2). Reinsemination of cows in estrus and at a fixed time did not

Table 2. Effect of presynchronization treatment ${ }^{1}$ on pattern of reinsemination, pregnancy per AI (P/AI) after reinsemination, and pregnancy rates

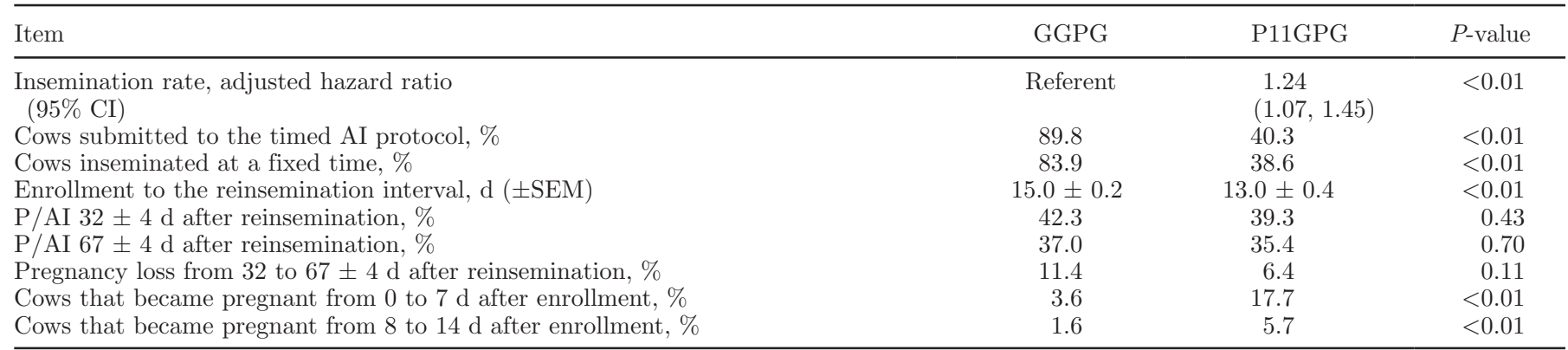

${ }^{1}$ Presynchronization treatments: GGPG = presynchronizing injection of GnRH (100 $\mu \mathrm{g}$ of gonadorelin hydrocloride; Factrel, Pfizer Animal Health, Madison, NJ) on d 0 (day of enrollment) and submission to the timed AI protocol on d 7 if not observed in estrus; P11GPG = presynchronizing injection of $\mathrm{PGF}_{2 \times}$ (25 mg of dinoprost tromethamine; Lutalyse, Pfizer Animal Health) on d 3 and submission to the timed AI protocol on d 11 if not observed in estrus. Cows submitted to the timed AI protocol were assigned randomly to receive or not receive a CIDR insert (1.38 g of $\mathrm{P}_{4}$; Eazi-Breed CIDR, Pfizer Animal Health) from the first GnRH injection to the $\mathrm{PGF}_{2 \alpha}$ injection of the timed AI protocol. Timed AI protocols were the Ovsynch56 ( $\mathrm{GnRH}, 7 \mathrm{~d}$ later $\mathrm{PGF}_{2 \alpha}, 56 \mathrm{~h}$ later $\mathrm{GnRH}$, and 12 to $16 \mathrm{~h}$ later fixed time $\left.\mathrm{AI}\right)$ in site A and the Cosynch48 (GnRH, 7 d later $\mathrm{PGF}_{2 \alpha}, 48 \mathrm{~h}$ later $\mathrm{GnRH}$ and fixed time $\left.\mathrm{AI}\right)$ in site $\mathrm{B}$. 


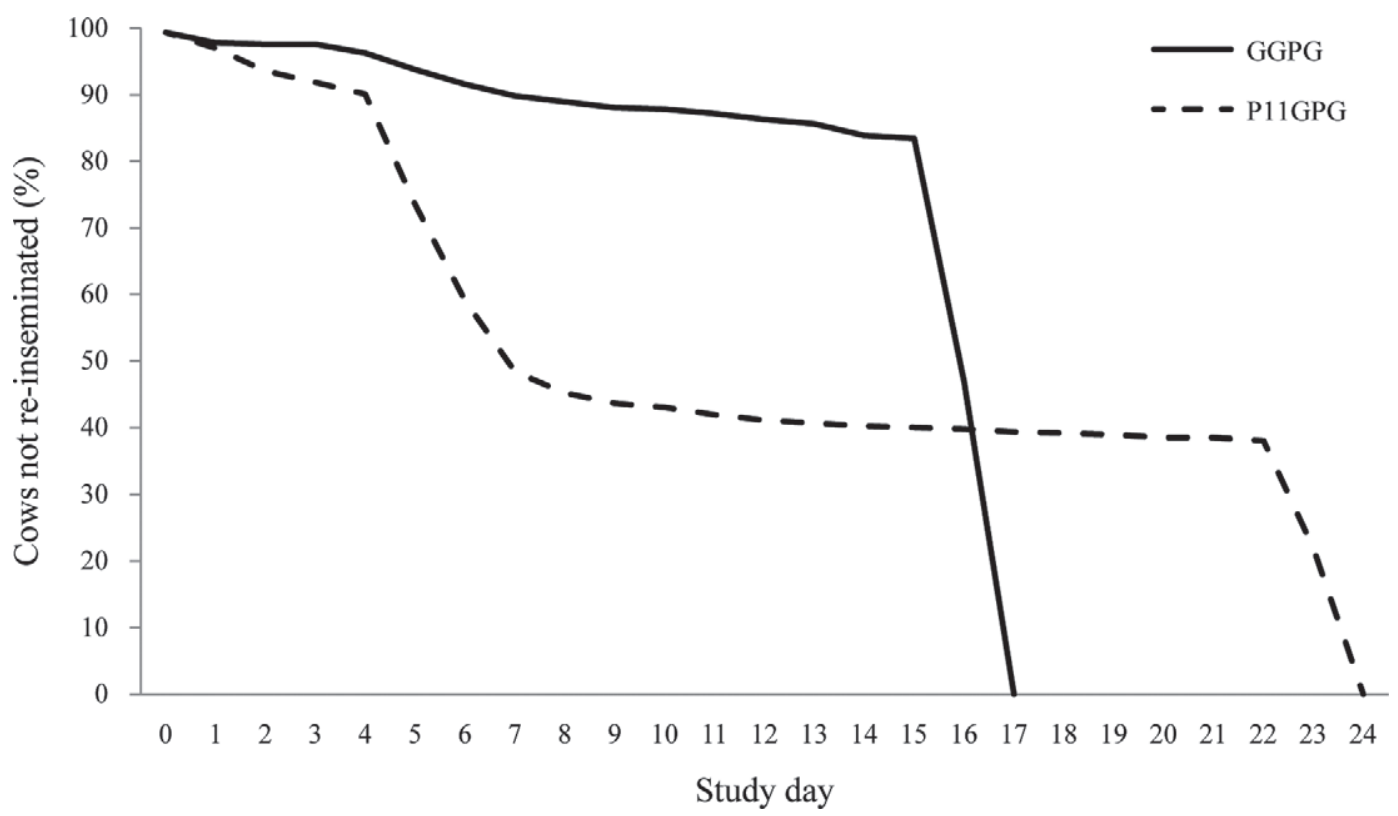

Figure 2. Survival analysis of the interval from enrollment to reinsemination according to presynchronization treatment (Wilcoxon test of equality, $P<0.01)$. Presynchronization treatments: GGPG = presynchronizing injection of GnRH (100 $\mu \mathrm{g}$ of gonadorelin hydrocloride; Factrel, Pfizer Animal Health, Madison, NJ) on d 0 (day of enrollment) and submission to the timed AI (TAI) protocol on d 7 if not observed in estrus; $\mathrm{P} 11 \mathrm{GPG}=$ presynchronizing injection of $\mathrm{PGF}_{2 \alpha}(25 \mathrm{mg}$ of dinoprost tromethamine; Lutalyse, Pfizer Animal Health) on d 3 and submission to

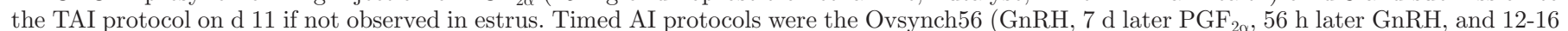
$\mathrm{h}$ later fixed time $\mathrm{AI})$ in site A and the Cosynch48 $\left(\mathrm{GnRH}, 7 \mathrm{~d}\right.$ later $\mathrm{PGF}_{2 \alpha}, 48 \mathrm{~h}$ later $\mathrm{GnRH}$ and fixed time AI) in site B. Mean $( \pm \mathrm{SEM})$ and median, respectively, intervals from enrollment to reinsemination: GGPG $=15.0 \pm 0.2 \mathrm{~d}$ and $16 \mathrm{~d} ; \mathrm{P} 11 \mathrm{GPG}=13.0 \pm 0.4 \mathrm{~d}$ and $8 \mathrm{~d}$.

$(P=0.47)$ affect $\mathrm{P} / \mathrm{AI} 67 \pm 4 \mathrm{~d}$ after reinsemination (estrus $=35.2 \%$ vs. fixed time $=36.8 \%$ ). Furthermore, the interaction between presynchronization treatment and reinsemination type did not affect $(P=0.41) \mathrm{P} / \mathrm{AI}$ $67 \pm 4 \mathrm{~d}$ after reinsemination (Figure 3 ). The percentage of cows that had a pregnancy loss from 32 to $67 \pm$ $4 \mathrm{~d}$ after reinsemination was not affected $(P=0.11)$ by presynchronization treatment (Table 2 ). The percentage of cows reinseminated in estrus $(6.8 \%)$ that had a pregnancy loss from 32 to $67 \pm 4 \mathrm{~d}$ after reinsemination was not $(P=0.69)$ different from the percentage of cows reinseminated at a fixed time $(10.3 \%)$, and the interaction between presynchronization treatment and reinsemination type did not affect $(P=0.22)$ pregnancy loss.

Among a subgroup of cows from site A that had their ovaries examined by ultrasound at the time of the nonpregnancy diagnosis, the interaction between presynchronization treatment and the presence of a CL on the day of the nonpregnancy diagnosis tended to affect $(P=0.10) \mathrm{P} / \mathrm{AI} 32 \pm 4 \mathrm{~d}$ after reinsemination (Figure 4). Among cows with a CL at the time of the nonpregnancy diagnosis, cows in the GGPG and P11GPG groups had similar P/AI, but among cows without a CL at the time of the nonpregnancy diagnosis, cows in the GGPG group had greater P/AI than cows in the P11GPG group (Figure 4). The presence of a CL at the time of the nonpregnancy diagnosis, however, did not $(P=0.96)$ affect $\mathrm{P} / \mathrm{AI} 32 \pm 4 \mathrm{~d}$ after reinsemination $(\mathrm{CL}+=33.3 \%$ vs. $\mathrm{CL}-=34.9 \%)$. The interaction between presynchronization treatment and the presence of a CL on the day of the nonpregnancy diagnosis did not affect $\mathrm{P} / \mathrm{AI} 67 \pm 4 \mathrm{~d}$ after reinsemination $(P=0.22)$ and pregnancy loss between $32 \pm 4$ and $67 \pm 4 \mathrm{~d}$ after reinsemination $(P=0.95$; Figure 4). Similarly, the presence of a CL on the day of the nonpregnancy diagnosis did not affect $\mathrm{P} / \mathrm{AI} 67 \pm 4 \mathrm{~d}$ after reinsemination $(\mathrm{CL}+=30.3 \%$ vs. $\mathrm{CL}-=30.1 \%$; $P=0.85)$ and pregnancy loss between $32 \pm 4$ and 67 $\pm 4 \mathrm{~d}$ after reinsemination $(\mathrm{CL}+=5.6 \%$ vs. $\mathrm{CL}-=$ $8.8 \% ; P=0.77)$.

The percentage of cows that became pregnant between $\mathrm{d} 0$ and 7 was reduced $(P<0.01)$ for cows in the GGPG group compared with those in the P11GPG group (Table 2). Similarly, the percentage of cows that became pregnant from d 8 to 14 was reduced $(P<$ 0.01) for cows in the GGPG group compared with those in the P11GPG group (Table 2). Among cows that became pregnant, the interval from enrollment to pregnancy was longer $(P<0.01)$ for cows in the GGPG group compared with those in the P11GPG group (15.2 \pm 0.5 vs. $12.5 \pm 0.5 \mathrm{~d}$ ). 
- GGPG/Estrus

$\square$ GGPG/TAI

๑ P11GPG/Estrus

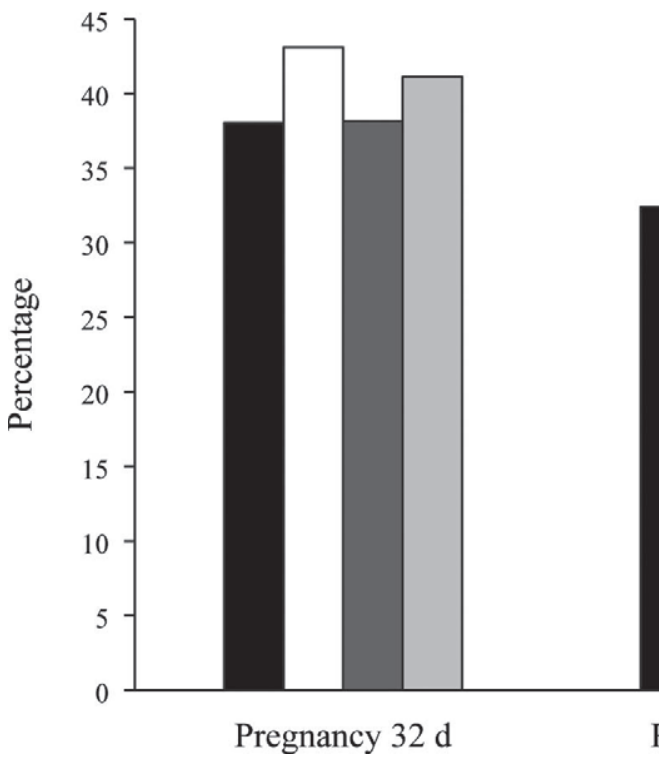

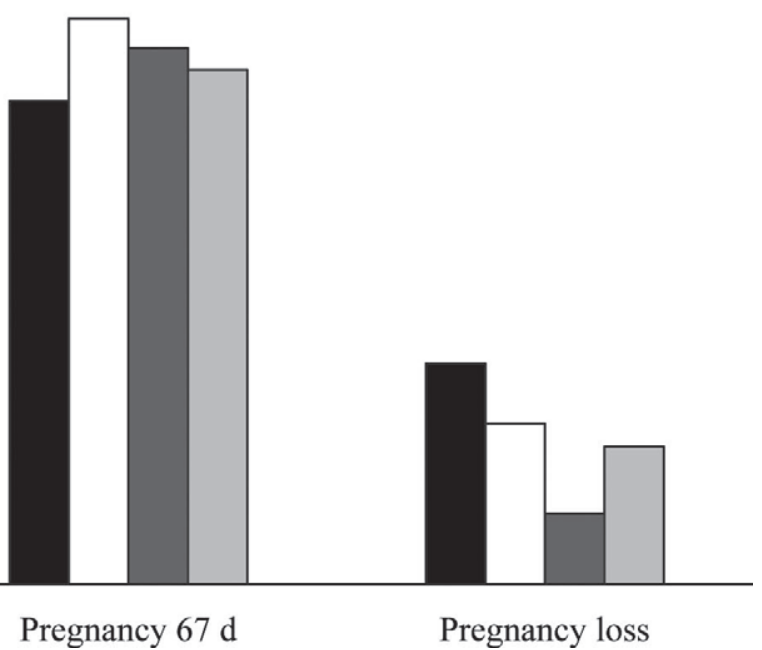

Pregnancy loss

Figure 3. Effect of the interaction between presynchronization treatment and reinsemination type [estrus vs. timed AI (TAI)] on pregnancy per AI 32 and $67 \pm 4 \mathrm{~d}$ after reinsemination and pregnancy loss from 32 to $67 \pm 4 \mathrm{~d}$ after reinsemination. Presynchronization treatments: GGPG = presynchronizing injection of GnRH (100 $\mathrm{g}$ of gonadorelin hydrocloride; Factrel, Pfizer Animal Health, Madison, NJ) on d 0 (day of enrollment) and submission to the timed AI (TAI) protocol on $\mathrm{d} 7$ if not observed in estrus. Cows submitted to the timed AI protocol were assigned randomly to receive or not receive a CIDR insert (1.38 $\mathrm{g}$ of $\mathrm{P}_{4}$; Eazi-Breed CIDR, Pfizer Animal Health) from the first GnRH injection to the $\mathrm{PGF}_{2 \alpha}$ injection of the timed AI protocol. Timed AI protocols were the Ovsynch56 ( $\mathrm{GnRH}, 7 \mathrm{~d}$ later $\mathrm{PGF}{ }_{2 \alpha}, 56 \mathrm{~h}$ later $\mathrm{GnRH}$, and 12 to $16 \mathrm{~h}$ later fixed time $\mathrm{AI})$ in site $\mathrm{A}$ and the Cosynch48 $\left(\mathrm{GnRH}, 7 \mathrm{~d}\right.$ later $\mathrm{PGF}_{2 \alpha}, 48 \mathrm{~h}$ later $\mathrm{GnRH}$ and fixed time AI) in site B. P11GPG $=$ presynchronizing injection of $\mathrm{PGF}_{2 \alpha}$ (25 mg of dinoprost tromethamine; Lutalyse, Pfizer Animal Health) on d 3 and submission to the TAI protocol on d 11 if not observed in estrus. Pregnancy per AI $32 \pm 4 \mathrm{~d}$ after reinsemination: presynchronization treatment, $P=0.43$; reinsemination type, $P=0.23$; and presynchronization treatment $\times$ reinsemination type interaction, $P=0.82$. Pregnancy per AI $67 \pm 4 \mathrm{~d}$ after reinsemination: presynchronization treatment, $P=0.70$; reinsemination type, $P=0.47$; and presynchronization treatment $\times$ reinsemination type interaction, $P$ $=0.41$. Pregnancy loss from 32 to $67 \pm 4 \mathrm{~d}$ after reinsemination: presynchronization treatment, $P=0.11$; reinsemination type, $P=0.69$; and presynchronization treatment $\times$ reinsemination type interaction, $P=0.22$.

\section{Pregnancy per Insemination of Cows Reinseminated at a Fixed Time}

Among cows submitted to the timed AI protocol, presynchronization treatment $(P=0.55)$, CIDR treatment $(P=1.00)$, and the interaction between presynchronization and CIDR treatment did not affect $(P=$ 0.90) $\mathrm{P} / \mathrm{AI} 32 \pm 4 \mathrm{~d}$ after reinsemination (Figure 5). Pregnancy per AI $67 \pm 4 \mathrm{~d}$ after reinsemination of cows submitted to the timed AI protocol was not affected by presynchronization treatment $(P=0.41)$, CIDR treatment $(P=0.75)$, or the interaction between presynchronization and CIDR treatment $(P=0.64$; Figure 5). Finally, pregnancy loss from 32 to $67 \pm 4 \mathrm{~d}$ after reinsemination among cows submitted to the timed AI protocol was not affected by presynchronization treatment $(P=0.63)$, CIDR treatment $(P=0.36)$, or the interaction between presynchronization and CIDR treatment $(P=0.28$; Figure 5$)$.

\section{Ovarian and P4 Responses}

Percentage of cows that had a CL on d 0 was not different $(P=0.36)$ between presynchronization treatments (Table 3$)$. On the other hand, a greater $(P<$ 0.01) percentage of cows in the GGPG group had a CL on the day of the first GnRH injection of the timed AI protocol compared with those in the P11GPG group (Table 3). Consequently, P4 concentration was greater $(P<0.01)$ for cows in the GGPG group than for those in the P11GPG group on the day of the first GnRH injection of the timed AI protocol, and a greater $(P<$ 0.01) percentage of cows in the GGPG group had P4 $\geq 1.0 \mathrm{ng} / \mathrm{mL}$ on the day of the first $\mathrm{GnRH}$ injection of the timed AI protocol (Table 3 ).

A reduced $(P<0.01)$ percentage of cows in the GGPG group ovulated in response to the first $\mathrm{GnRH}$ injection of the timed AI protocol compared with cows in the P11GPG group (Table 3). On the other hand, 


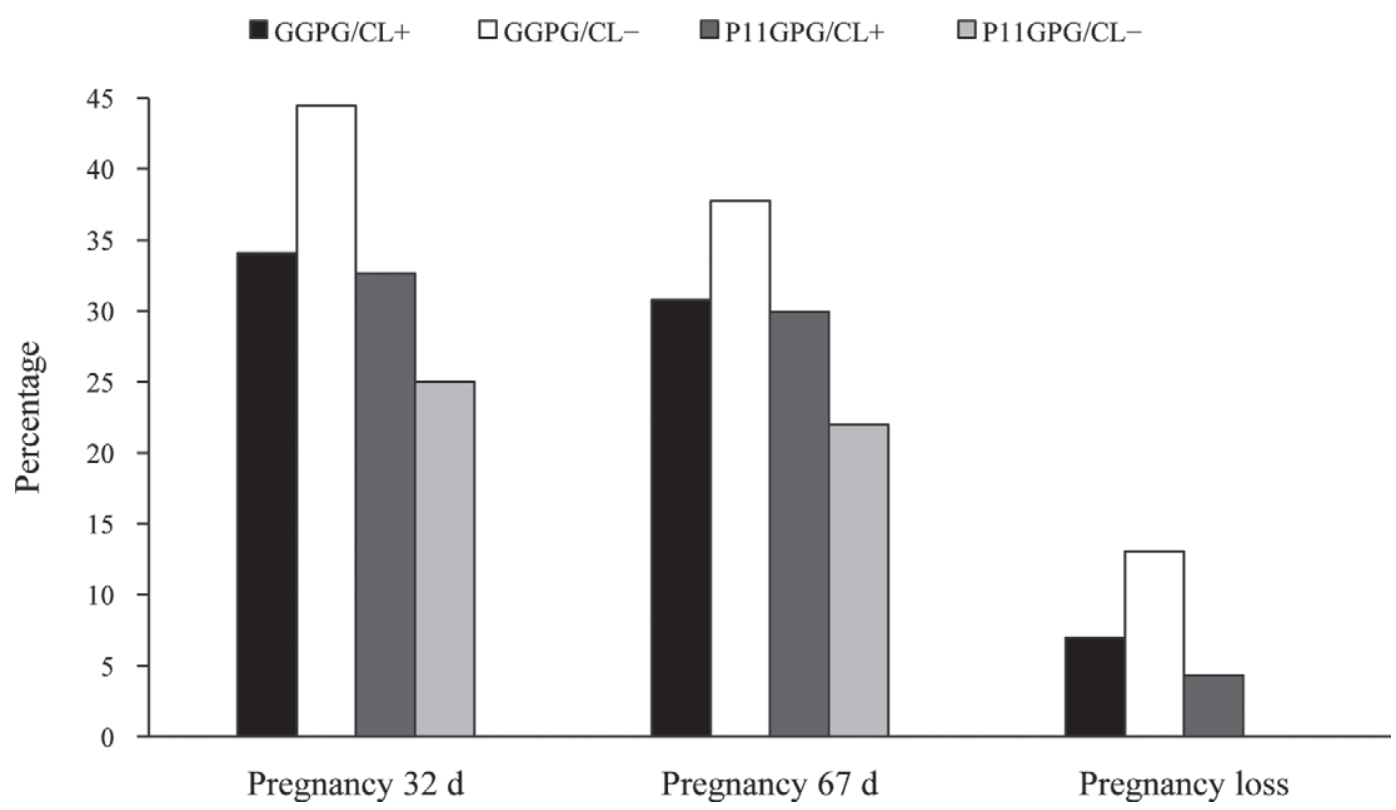

Figure 4. Effect of the interaction between presynchronization treatment and presence of a corpus luteum $(\mathrm{CL} ; \mathrm{present}=\mathrm{CL}+\mathrm{vs}$. absent $=\mathrm{CL}-$ ) on the day of nonpregnancy diagnosis on pregnancy per AI (P/AI) 32 and $67 \pm 4 \mathrm{~d}$ after reinsemination and pregnancy loss from 32 to $67 \pm 4 \mathrm{~d}$ after reinsemination in a subgroup of cows from site $\mathrm{A}(\mathrm{GGPG}=186, \mathrm{P} 11 \mathrm{GPG}=202)$. Presynchronization treatments: GGPG = presynchronizing injection of GnRH (100 $\mu \mathrm{g}$ of gonadorelin hydrocloride; Factrel, Pfizer Animal Health, Madison, NJ) on d 0 (day of enrollment) and submission to the timed AI (TAI) protocol on d 7 if not observed in estrus. Cows submitted to the timed AI protocol were assigned randomly to receive or not receive a CIDR insert (1.38 $\mathrm{g}$ of $\mathrm{P}_{4}$; Eazi-Breed CIDR, Pfizer Animal Health) from the first GnRH injection to the $\mathrm{PGF}_{2 \alpha}$ injection of the timed AI protocol. Timed AI protocols were the Ovsynch56 (GnRH, $7 \mathrm{~d}$ later PGF $2 \alpha, 56 \mathrm{~h} \mathrm{later} \mathrm{GnRH,} \mathrm{and} 12$ to $16 \mathrm{~h}$ later fixed time $\mathrm{AI}$ ) in site $\mathrm{A}$ and the Cosynch48 (GnRH, $7 \mathrm{~d}$ later $\mathrm{PGF}_{2 \alpha}, 48 \mathrm{~h}$ later $\mathrm{GnRH}$ and fixed time $\left.\mathrm{AI}\right)$ in site $\mathrm{B}$. P11GPG = presynchronizing injection of $\mathrm{PGF}_{2 \alpha}$ (25 mg of dinoprost tromethamine; Lutalyse, Pfizer Animal Health) on d 3 and submission to the TAI protocol on $\mathrm{d} 11$ if not observed in estrus. Effect of the interaction between presynchronization treatment and presence of a CL on $\mathrm{P} / \mathrm{AI} 32 \pm 4 \mathrm{~d}$ after reinsemination, $P=0.10 ; \mathrm{P} / \mathrm{AI} 67 \pm 4 \mathrm{~d}$ after reinsemination, $P=0.22$; pregnancy loss from 32 to $67 \mathrm{~d}$ after reinsemination, $P=0.95$.

CIDR treatment $(P=0.71)$ and the interaction between presynchronization and CIDR treatments $(P=0.46)$ did not affect the percentage of cows that ovulated in response to the first GnRH injection of the timed AI protocol.

Percentage of cows that had a CL on the day of the $\mathrm{PGF}_{2 \alpha}$ injection of the timed $\mathrm{AI}$ protocol was not affected by presynchronization treatment $(P=0.19$; Table 3), CIDR treatment $(P=0.60)$, or the interaction between presynchronization and CIDR treatment $(P=0.90)$. Similarly, $\mathrm{P} 4$ concentration on the day of the $\mathrm{PGF}_{2 \alpha}$ injection of the timed AI protocol $(P=$ 0.69 ) and percentage of cows with $\mathrm{P} 4 \geq 1.0 \mathrm{ng} / \mathrm{mL}$ on the day of the $\mathrm{PGF}_{2 \alpha}$ of the fixed-time $\mathrm{AI}(P=0.47)$ were not different between presynchronization treatments (Table 3). Progesterone concentration on the day of the $\mathrm{PGF}_{2 \alpha}$ injection of the timed $\mathrm{AI}$ protocol was not affected by CIDR treatment $(P=0.73)$ or by the interaction between presynchronization and CIDR treatments $(P=0.79)$.

Finally, P4 concentration on the day of fixed-time AI was not affected by presynchronization treatment $(P=0.95$; Table 3$)$, CIDR treatment $(P=0.94)$, or the interaction between presynchronization and CIDR treatments $(P=0.44)$. Similarly, percentage of cows with $\mathrm{P} 4<1 \mathrm{ng} / \mathrm{mL}$ on the day of fixed-time AI was not affected by presynchronization treatment $(P=0.17$; Table 3), CIDR treatment $(P=0.62)$, or the interaction between presynchronization and CIDR treatments $(P=0.82)$. Percentage of cows with their estrous cycle synchronized was not affected by presynchronization treatment $(P=0.30)$, CIDR treatment $(P=0.29)$, or the interaction between presynchronization and CIDR treatment $(P=0.34)$.

\section{DISCUSSION}

Pregnancy per AI of nonpregnant cows that had their estrous cycle presynchronized with $\mathrm{GnRH}$ or $\mathrm{PGF}_{2 \alpha}$ injections at 7 and $11 \mathrm{~d}$, respectively, before the start of the timed AI protocol were not different. Furthermore, $\mathrm{P} / \mathrm{AI}$ of cows in the GGPG and P11GPG groups were similar regardless of whether the cows were reinseminated in estrus or at a fixed time. Because presynchronization of the estrous cycle of nonpregnant cows with $\mathrm{PGF}_{2 \alpha}$ resulted in an expedited reinsemination rate, the interval to reinsemination and to the establishment of pregnancy was shorter for cows in the P11GPG group. 
Table 3. Effect of presynchronization treatment ${ }^{1}$ on ovarian and progesterone $(\mathrm{P} 4)$ responses

\begin{tabular}{|c|c|c|c|}
\hline Item & GGPG & P11GPG & $P$-value \\
\hline Cows bearing a CL on the day of the first GnRH injection of the timed AI protocol, \% & 93.6 & 67.2 & $<0.01$ \\
\hline Cows ovulating in response to the first GnRH injection of the timed AI protocol, \% & 46.8 & 66.1 & $<0.01$ \\
\hline \multicolumn{4}{|l|}{$\mathrm{P} 4$ concentration, ng/mL ( \pm SEM $)$} \\
\hline Day of the first GnRH of the fixed-time AI & $3.7 \pm 0.3$ & $2.2 \pm 0.4$ & $<0.01$ \\
\hline Day of the $\mathrm{PGF}_{2 \alpha}$ of the fixed-time $\mathrm{AI}$ & $4.0 \pm 0.3$ & $4.2 \pm 0.4$ & 0.69 \\
\hline Cows with $\mathrm{P} 4 \geq 1 \mathrm{ng} / \mathrm{mL}$ on the day of the $\mathrm{PGF}_{2 \alpha}$ of the fixed-time AI, $\%$ & 79.4 & 75.8 & 0.47 \\
\hline Cows with $\mathrm{P} 4<1 \mathrm{ng} / \mathrm{mL}$ on the day of the fixed-time AI, $\%$ & 95.8 & 89.8 & 0.17 \\
\hline Cows with estrous cycle synchronized, \% & 76.1 & 67.8 & 0.30 \\
\hline
\end{tabular}

${ }^{1}$ Presynchronization treatments: GGPG = presynchronizing injection of GnRH (100 $\mu \mathrm{g}$ of gonadorelin hydrocloride; Factrel, Pfizer Animal Health, Madison, NJ) on d 0 (day of enrollment) and submission to the timed AI protocol on d 7 if not observed in estrus; P11GPG = presynchronizing injection of $\mathrm{PGF}_{2 \alpha}$ (25 mg of dinoprost tromethamine; Lutalyse, Pfizer Animal Health) on d 3 and submission to the timed AI protocol on $\mathrm{d} 11$ if not observed in estrus. $\mathrm{CL}=$ corpus luteum. Cows submitted to the timed AI protocol were assigned randomly to receive or not receive a CIDR insert (1.38 $\mathrm{g}$ of $\mathrm{P}_{4}$; Eazi-Breed CIDR, Pfizer Animal Health) from the first GnRH injection to the PGF ${ }_{2 \alpha}$ injection of the timed AI protocol. Timed AI protocols were the Ovsynch56 (GnRH, 7 d later $\mathrm{PGF}_{2 \alpha}, 56$ h later $\mathrm{GnRH}$, and 12 to $16 \mathrm{~h}$ later fixed time AI) in site $\mathrm{A}$ and the Cosynch48 (GnRH, 7 d later $\mathrm{PGF}_{2 \alpha}, 48 \mathrm{~h}$ later $\mathrm{GnRH}$ and fixed time $\left.\mathrm{AI}\right)$ in site $\mathrm{B}$.

This was expected because an injection of $\mathrm{PGF}_{2 \alpha}$ is expected to cause luteolysis in 60 to $85 \%$ of heifers and cows (Colazo et al., 2002; Chebel et al., 2007). Furthermore, treatment of cows with $\mathrm{PGF}_{2 \alpha}$ results in a decline in $\mathrm{P} 4$ concentration of approximately 70 and $80 \%$ of the initial $\mathrm{P} 4$ concentration within 12 and $48 \mathrm{~h}$, respectively, of $\mathrm{PGF}_{2 \alpha}$ treatment (Chebel et al., 2007). Consequently, the majority of cows that display

- GGPG $\square$ GGPG+CIDR $\square$ P11GPG $\square$ P11GPG+CIDR

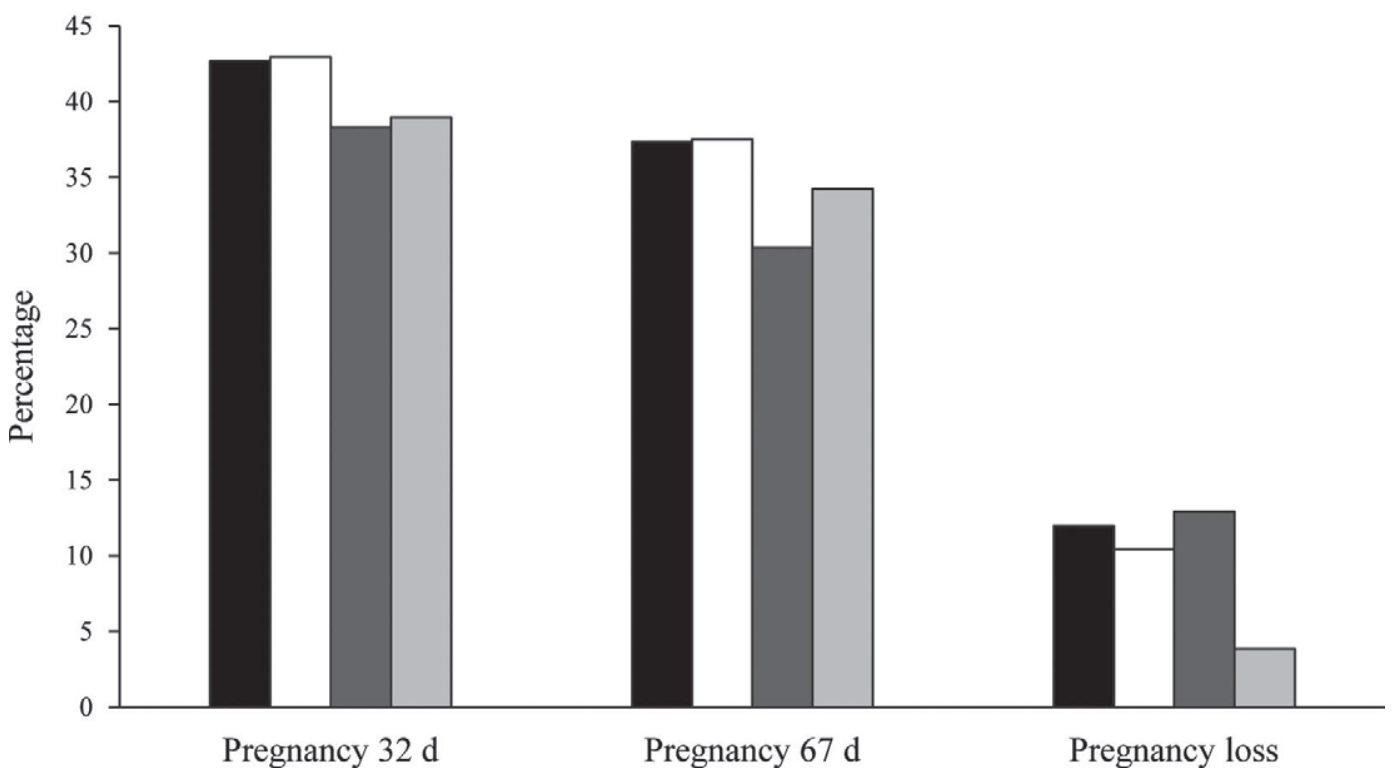

Figure 5. Effect of the presynchronization treatment, controlled internal drug-releasing (CIDR) treatment, and the interaction between presynchronization and CIDR treatments on pregnancy per AI 32 and $67 \pm 4 \mathrm{~d}$ after reinsemination and pregnancy loss from 32 to $67 \pm 4 \mathrm{~d}$ after reinsemination of cows submitted to the timed AI (TAI) protocol. Presynchronization treatments: GGPG = presynchronizing injection of GnRH $(100 \mu \mathrm{g}$ of gonadorelin hydrocloride; Factrel, Pfizer Animal Health, Madison, NJ) on d 0 (day of enrollment) and submission to the TAI protocol on $\mathrm{d} 7$ if not observed in estrus. Cows submitted to the timed AI protocol were assigned randomly to receive or not receive a CIDR insert (1.38 $\mathrm{g}$ of $\mathrm{P}_{4}$; Eazi-Breed CIDR, Pfizer Animal Health) from the first GnRH injection to the $\mathrm{PGF}_{2 \alpha}$ injection of the timed AI protocol. Timed AI protocols were the Ovsynch56 (GnRH, 7 d later $\mathrm{PGF}_{2 \alpha}, 56 \mathrm{~h}$ later $\mathrm{GnRH}$, and 12 to 16 h later fixed time AI) in site A and the Cosynch48 (GnRH, $7 \mathrm{~d}$ later $\mathrm{PGF}_{2 \alpha}, 48 \mathrm{~h}$ later $\mathrm{GnRH}$ and fixed time $\left.\mathrm{AI}\right)$ in site $\mathrm{B} . \mathrm{P} 11 \mathrm{GPG}=$ presynchronizing injection of $\mathrm{PGF} \mathrm{F}_{2 \alpha}(25 \mathrm{mg}$ of dinoprost tromethamine; Lutalyse, Pfizer Animal Health) on d 3 and submission to the TAI protocol on d 11 if not observed in estrus. Pregnancy per AI $32 \pm 4 \mathrm{~d}$ after reinsemination: presynchronization treatment, $P=0.55$; CIDR treatment, $P=1.00$; and presynchronization treatment $\times$ CIDR treatment, $P=0.90$. Pregnancy per AI $67 \pm 4 \mathrm{~d}$ after reinsemination: presynchronization treatment, $P=0.41$; CIDR treatment, $P=0.75$; and presynchronization treatment $\times$ CIDR treatment, $P=0.64$. Pregnancy loss from 32 to $67 \pm 4 \mathrm{~d}$ after reinsemination: presynchronization treatment, $P=0.63$; CIDR treatment, $P=0.36$; and presynchronization treatment $\times$ CIDR treatment, $P=0.28$. 
estrus after $\mathrm{PGF}_{2 \alpha}$ treatment do so between 2 and $8 \mathrm{~d}$ after $\mathrm{PGF}_{2 \alpha}$ treatment (Chebel et al., 2006). On the other hand, GnRH injections are not expected to induce estrus because they are followed by a surge of LH within $1 \mathrm{~h}$ after treatment that causes ovulation of the dominant follicles (Stevenson et al., 2004), and treatment with $\mathrm{GnRH}$ may downregulate the expression of aromatase in granulosa cells, reducing the secretion of estradiol by the dominant follicle (Fitzpatrick et al., 1997). Recent studies demonstrated that the percentages of nonpregnant cows reinseminated in estrus after a presynchronizing injection of GnRH given $17 \pm 3$, $24 \pm 3$, or $31 \pm 3 \mathrm{~d}$ after a previous insemination were reduced by 50 to $70 \%$ (Bruno et al., 2011; Mendonça et al., 2011; Moraes et al., 2011). Thus, the greater pregnancy rates of cows in the P11GPG group between $d 0$ and 7 and between $\mathrm{d} 8$ and 14 compared with cows in the GGPG group was expected. This is important because the increased expression of estrus in cows in the P11GPG group resulted in fewer cows in the P11GPG group being submitted to the timed AI protocol, which would reduce the cost of the resynchronization protocol and shorten the interval to reinsemination and to establishment of pregnancy in cows in the P11GPG group compared with cows in the GGPG group. Furthermore, the P11GPG protocol represents a good alternative for dairy producers who achieve adequate estrous detection rates and who intend to reduce the use of reproductive hormones.

Since the development of timed AI protocols in the 1990s, it has become evident that timed AI protocols have to be initiated between d 5 and 9 of the estrous cycle to ensure ovulation in response to the first $\mathrm{GnRH}$ of the timed AI protocol (Vasconcelos et al., 1999) and growth of the dominant follicle under elevated $\mathrm{P} 4$ concentrations (P4 $\geq 2 \mathrm{ng} / \mathrm{mL}$; Sartori et al., 2004), which are key factors for embryo quality and $\mathrm{P} / \mathrm{AI}$ after timed AI protocols (Chebel et al., 2006; Cerri et al., 2009b; Rivera et al., 2011; Denicol et al., 2012). Presynchronization of the estrous cycle of cows with $\mathrm{PGF}_{2 \alpha}$ before the start of timed AI protocols has been used extensively, particularly for the first postpartum AI. Because the majority of cows that display estrus after $\mathrm{PGF}_{2 \alpha}$ treatment do so between 2 and $7 \mathrm{~d}$ after treatment (Chebel et al., 2006), when the timed AI protocol is begun $11 \mathrm{~d}$ after a presynchronizing $\mathrm{PGF}_{2 \alpha}$ injection, the majority of cows that display estrus would be between d 4 and 9 of the estrous cycle at the start of the timed AI protocol. Silva et al. (2007) demonstrated that cows diagnosed as nonpregnant to a previous AI that had their estrous cycle presynchronized with $\mathrm{PGF}_{2 \alpha} 12 \mathrm{~d}$ before the start of the timed $\mathrm{AI}$ protocol had greater $\mathrm{P} / \mathrm{AI}$ to reinsemination than cows that did not have their estrous cycle presynchronized. Cows, however, were not allowed to be reinseminated in estrus, which resulted in a longer interval from nonpregnancy diagnosis to reinsemination (Silva et al., 2007). Presynchronization of the estrous cycle with GnRH $7 \mathrm{~d}$ before the start of a timed AI protocol has been demonstrated to increase the $\mathrm{P} / \mathrm{AI}$ of lactating dairy cows in several recent studies (Dewey et al., 2010; Bruno et al., 2011; Lopes et al., 2011). The presynchronizing $\mathrm{GnRH}$ injection is expected to cause ovulation within $30 \mathrm{~h}$ of treatment and recruitment of a new follicular wave within $48 \mathrm{~h}$ of treatment in a large percentage of cows that have a follicle $\geq 10 \mathrm{~mm}$ in diameter (Pursley et al., 1995). This is the basis of the presynchronization with GnRH because cows that ovulate to the presynchronizing $\mathrm{GnRH}$ injection would have a large dominant follicle likely responsive to the first GnRH injection of the timed AI protocol and would have $\mathrm{P} 4$ concentration $\geq 2 \mathrm{ng} / \mathrm{mL}$ from the beginning of the timed $\mathrm{AI}$ protocol until the day of $\mathrm{PGF}_{2 \alpha}$ injection. In a recent experiment, however, presynchronization of the estrous cycle with GnRH $7 \mathrm{~d}$ before the start of a timed AI protocol did not improve P/AI (Alkar et al., 2011). It is not clear why, in the latter experiment, presynchronization of the estrous cycle with $\mathrm{GnRH}$ did not improve $\mathrm{P} / \mathrm{AI}$, but it is possible that the interval from previous AI to the presynchronizing injection of GnRH, $28 \pm 3$ d, was not ideal. In studies conducted by our group and others (Dewey et al., 2010; Bruno et al., 2011; Lopes et al., 2011), we concluded that the presynchronizing injections of $\mathrm{GnRH}$ are beneficial when given at $17 \pm 3$ and $31 \pm 3 \mathrm{~d}$ after a previous $\mathrm{AI}(7 \mathrm{~d}$ before the start of the timed AI protocol) compared with nonpresynchronized cows that start the timed AI protocol $24 \pm 3$ and $38 \pm 3 \mathrm{~d}$, respectively, after a previous AI. Caution should be exerted, however, when starting the presynchronization with $\mathrm{GnRH}$ early after a previous AI (i.e., $17 \mathrm{~d}$ ) because of the reduced expression of estrus as a consequence of the GnRH treatment (Bruno et al., 2011; Moraes et al., 2011).

In a subgroup of cows from site $\mathrm{A}$, we observed that the interaction between presynchronization treatment and the presence of a CL on the day of the nonpregnancy diagnosis tended to be associated with $\mathrm{P} / \mathrm{AI} 32$ $\pm 4 \mathrm{~d}$ after reinsemination. The number of cows was not sufficient to determine whether a 3 -way interaction (presynchronization treatment $\times$ CIDR treatment $\times$ presence of a CL on the day of the nonpregnancy diagnosis) would affect P/AI. Nonetheless, the increased $\mathrm{P} / \mathrm{AI}$ of cows in the GGPG group that did not have a CL on the day of the nonpregnancy diagnosis may result from the presynchronizing $\mathrm{GnRH}$-induced ovulation that would have increased $\mathrm{P} 4$ concentration during growth of the ovulatory follicle.

Among cows reinseminated at a fixed time, the presynchronization treatment did not affect $\mathrm{P} / \mathrm{AI}$, despite 
the fact that a large percentage of cows in the P11GPG group were reinseminated in estrus. Furthermore, as mentioned previously, reinsemination in estrus or at a fixed time did not affect P/AI of cows in the GGPG and P11GPG groups. This demonstrates that, in herds with efficacious and accurate estrous detection, implementation of estrous cycle presynchronization protocols that induce estrus may be used with no detriment to the $\mathrm{P} /$ $\mathrm{AI}$ of cows reinseminated in estrus or at a fixed time. On the other hand, in herds with inadequate estrous detection accuracy, estrous cycle presynchronization protocols based on GnRH injections are likely to be more beneficial. Regardless of the presynchronization treatment, however, CIDR treatment did not improve the P/AI of cows reinseminated at a fixed time. Treatment of nonpregnant, lactating dairy cows with a CIDR insert during the timed AI protocol has resulted in greater P/AI (Dewey et al., 2010; Bilby et al., 2011), but in these studies, cows did not have their estrous cycle presynchronized with either $\mathrm{GnRH}$ or $\mathrm{PGF}_{2 \alpha}$. It is important to observe that because of the elevated number of cows in the P11GPG group that were reinseminated in estrus, the number in the P11GPG group reinseminated at a fixed time was significantly smaller than originally planned and was likely insufficient to detect statistical significance when the difference in $\mathrm{P} / \mathrm{AI}$ of cows in the P11GPG group treated and not treated with a CIDR was 4 percentage units.

A greater percentage of cows in the GGPG group had a CL and $\mathrm{P} 4 \geq 1 \mathrm{ng} / \mathrm{mL}$ on the day of the first $\mathrm{GnRH}$ injection of the timed AI protocol compared with cows in the P11GPG group. Furthermore, cows in the GGPG group had a greater $\mathrm{P} 4$ concentration than cows in the P11GPG group on the day of the first GnRH injection of the timed AI protocol. These findings indicate that a larger percentage of cows in the GGPG group had ovulated recently before the start of the timed AI protocol, which was likely caused by the presynchronizing GnRH injection. Other studies have demonstrated that heifers and lactating dairy cows presynchronized with a GnRH injection 6 and $7 \mathrm{~d}$, respectively, before the start of a timed AI protocol were more likely to have a CL and $\mathrm{P} 4$ concentration $\geq 1 \mathrm{ng} / \mathrm{mL}$ at the start of the timed AI protocol (Stevenson et al., 2008; Dewey et al., 2010). As mentioned previously, treatment with GnRH causes ovulation within approximately $30 \mathrm{~h}$ after treatment, as well as formation of a new CL that might be identified $7 \mathrm{~d}$ later in cows that have a follicle $\geq 10 \mathrm{~mm}$ in diameter (Pursley et al., 1995).

The greater percentage of cows in the P11GPG group that ovulated in response to the first $\mathrm{GnRH}$ injection of the timed AI protocol may be associated with the reduced percentage of cows in the P11GPG group with $\mathrm{P} 4 \geq 1 \mathrm{ng} / \mathrm{mL}$ on the day of the first $\mathrm{GnRH}$ injection of the timed AI protocol. In recent experiments, beef heifers and cows (Colazo et al., 2008; Dias et al., 2010) and lactating dairy cows (Giordano et al., 2012) had a suppressed GnRH-induced LH surge when P4 concentration was elevated, whereas treatment of cows with a reduced $\mathrm{P} 4$ concentration with $\mathrm{GnRH}$ resulted in a more pronounced LH surge (Giordano et al., 2012). Furthermore, concentrations of $\mathrm{P} 4<1 \mathrm{ng} / \mathrm{mL}$ may hasten the development of dominant follicles because of the greater pulsatility of LH (Roberson et al., 1989; Sartori et al., 2004). Consequently, larger and more mature dominant follicles are expected to be more likely to ovulate in response to an LH surge (Sartori et al., 2001). It seems that the similar P/AI between cows in the GGPG and P11GPG groups that were inseminated at a fixed time is therefore the result of a compromise between elevated P4 concentration during growth of the ovulatory follicle and reduced ovulation in response to the first $\mathrm{GnRH}$ injection of the timed AI protocol in cows in the GGPG group and reduced P4 concentration during growth of the ovulatory follicle and increased ovulation in response to the first GnRH injection of the timed AI protocol in cows in the P11GPG group.

In conclusion, dairy herds with adequate estrous detection efficiency and accuracy may benefit from the P11GPG protocol because of the reduced interval between inseminations, the reduced use of reproductive hormones, and the expected reduced cost of the resynchronization protocol. On the other hand, dairy herds with inefficient or inaccurate estrous detection are likely to benefit from the GGPG protocol. As for the use of CIDR inserts in cows that are enrolled in the timed AI protocol, it appears from the current data that cows submitted to the GGPG protocol may not benefit from it as much as cows submitted to the P11GPG protocol. The latter affirmation, however, needs to be validated by experiments with a larger number of cows.

\section{ACKNOWLEDGMENTS}

We thank the owners and managers of New Sweden Dairy (Nicollet, MN) and Norswiss Dairy (Summit, SD). Furthermore, we thank Gary Neubauer, Jerry Olson (both of Pfizer Animal Health) and Pfizer Animal Health (Madison, NJ) for financial support and for donation of the Factrel, Lutalyse, and CIDR inserts.

\section{REFERENCES}

Alkar, A., A. Tibary, J. R. Wenz, R. L. Nebel, and R. Kasimanickam. 2011. Presynchronization with GnRH 7 days prior to resynchronization with CO-Synch did not improve pregnancy rate in lactating dairy cows. Theriogenology 76:1036-1041.

Bilby, T. R., R. G. S. Bruno, K. J. Lager, R. C. Chebel, J. G. N. Moraes, P. M. Fricke, G. Lopes, J. O. Giordano, J. E. P. Santos, F. 
S. Lima, J. S. Stevenson, and S. L. Pulley. 2011. Effects of supplemental progesterone and timing of initiation of resynchronization on fertility in lactating dairy cows. J. Dairy Sci. 94(E-Suppl. 1):88. (Abstr.)

Bruno, R .G. S., J. G. N. Moraes, J. A. H. Rivera, K. J. Lager, P. R. B. Silva, A. L. A. Scanavez, L. G. D. Mendonça, R. C. Chebel, and T. R. Bilby. 2011. Comparison of two resynchronization protocols initiated at different intervals after insemination on fertility in lactating dairy cows. J. Dairy Sci. 94(E-Suppl. 1):66. (Abstr.)

Cerri, R. L. A., H. M. Rutigliano, R. G. S. Bruno, and J. E. P. Santos. 2009a. Progesterone concentration, follicular development and induction of cyclicity in dairy cows receiving intravaginal progesterone inserts. Anim. Reprod. Sci. 110:56-70.

Cerri, R. L. A., H. M. Rutigliano, R. C. Chebel, and J. E. P. Santos, 2009b. Period of dominance of the ovulatory follicle during synchronization programs influences embryo quality. Reproduction 137:813-823.

Chebel, R. C., J. E. P. Santos, R. L. A. Cerri, H. M. Rutigliano, and R. G. S. Bruno. 2006. Reproductive performance of lactating dairy cows following progesterone insert based presynchronization and resynchronization protocols. J. Dairy Sci. 89:4205-4219.

Chebel, R. C., J. E. P. Santos, H. M. Rutigliano, and R. L. A. Cerri 2007. Efficacy of an injection of dinoprost tromethamine when given subcutaneously in two different sites on luteal regression in lactating Holstein cows. Theriogenology 67:590-597.

Colazo, M. G., J. P. Kastelic, H. Davis, M. D. Rutledge, M. F. Martinez, J. A. Small, and R. J. Mapletoft. 2008. Effects of plasma progesterone concentrations on LH release and ovulation in beef cattle given GnRH. Domest. Anim. Endocrinol. 34:109-117.

Colazo, M. G., M. F. Martinez, J. P. Kastelic, and R. J. Mapletoft. 2002. Effects of dose and route of administration of cloprostenol on luteolysis, estrus and ovulation in beef heifers. Anim. Reprod. Sci. $72: 47-62$.

Denicol, A. C., G. Lopes Jr., L. G. D. Mendonça, F. A. Rivera, F. Guagnini, R. V. Perez, J. R. Lima, R. G. S. Bruno, J. E. P. Santos, and R. C. Chebel. 2012. Low progesterone concentration during the development of the first follicular wave reduces pregnancy per insemination of lactating dairy cows. J. Dairy Sci. 95:1794-1806.

Dewey, S. T., L. G. Mendonça, G. Lopes Jr., F. A. Rivera, F. Guagnini, R. C. Chebel, and T. R. Bilby. 2010. Resynchronization strategies to improve fertility in lactating dairy cows utilizing a presynchronization injection of $\mathrm{GnRH}$ or supplemental progesterone: I. pregnancy rates and ovarian responses. J. Dairy Sci. 93:4086-4095.

Dias, F. C., M. G. Colazo, J. P. Kastelic, R. J. Mapletoft, G. P. Adams, and J. Singh. 2010. Progesterone concentration, estradiol pretreatment, and dose of gonadotropin-releasing hormone affect gonadotropin-releasing hormone-mediated luteinizing hormone release in beef heifers. Domest. Anim. Endocrinol. 39:155-162.

Fitzpatrick, S. L., D. L. Carlone, R. L. Robker, and J. S. Richards. 1997. Expression of aromatase in the ovary: down-regulation of mRNA by the ovulatory luteinizing hormone surge. Steroids 62:197-206.

Giordano, J. O., P. M. Fricke, J. N. Guenther, G. Lopes Jr., M. M. Herlihy, A. B. Nascimento, and M. C. Wiltbank. 2012. Effect of progesterone on magnitude of the luteinizing hormone surge in- duced by two different doses of gonadotropin-releasing hormone in lactating dairy cows. J. Dairy Sci. 95:3781-3793.

Lopes, G., Jr., J. O. Giordano, A. Valenza, M. M. Herlihy, J. N. Guenther, M. C. Wiltbank, and P. M. Fricke. 2011. Effect of timing of initiation of Resynch and presynchronization with $\mathrm{GnRH}$ on fertility of resynchronized inseminations in lactating dairy cows. J. Dairy Sci. 94(E-Suppl. 1):237. (Abstr.)

Mendonça, L. G. D., S. T. Dewey, G. Lopes Jr., F. A. Rivera, F. Guagnini, J. Fetrow, T. R. Bilby, and R. C. Chebel. 2011. Effects of resynchronization strategies for lactating Holstein cows on pattern of re-insemination, fertility, and economic outcome. Theriogenology $77: 1151-1158$.

Moraes, J. G. N., R. G. S. Bruno, P. R. B. Silva, A. L. A. Scanavez, L. G. D. Mendonça, J. A. Hernandez-Rivera, K. J. Lager, J. Fetrow, T. R. Bilby, and R.C. Chebel. 2011. Economic and fertility comparison of two resynchronization protocols for lactating dairy cows initiated at different intervals after insemination. J. Dairy Sci 94(E-Suppl. 1):351.

Pursley, J. R., M. O. Mee, and M. C. Wiltbank. 1995. Synchronization of ovulation in dairy cows using PGF2alpha and GnRH. Theriogenology 44:915-923.

Rivera, F. A., L. G. D. Mendonça, G. Lopes Jr., R. V. Perez, F. Guagnini, M. Amstalden, R. G. S. Bruno, J. E. P. Santos, and R. C. Chebel. 2011. Low progesterone concentration during superstimulation of the first follicular wave impairs embryo quality of lactating dairy cows. Reproduction 141:333-342.

Roberson, M. S., M. W. Wolfe, T. T. Stumpf, R. J. Kittok, and J. E. Kinder. 1989. Luteinizing hormone secretion and corpus luteum function in cows receiving two levels of P4. Biol. Reprod. 41:997-1003.

Sartori, R., P. M. Fricke, J. C. Ferreira, O. J. Ginther, and M. C. Wiltbank. 2001. Follicular deviation and acquisition of ovulatory capacity in bovine follicles. Biol. Reprod. 65:1403-1409.

Sartori, R., J. M. Haughian, R. D. Shaver, G. J. M. Rosa, and M. C. Wiltbank. 2004. Comparison of ovarian function and circulating steroids in oestrous cycles of Holstein heifers and lactating cows. J. Dairy Sci. 87:905-920.

Silva, E., R. A. Sterry, D. Kolb, M. C. Wiltbank, and P. M. Fricke. 2007. Effect of pretreatment with prostaglandin $\mathrm{F}_{2 \alpha}$ before resynchronization of ovulation on fertility of lactating dairy cows. J. Dairy Sci. 90:5509-5517.

Stevenson, J. L., J. C. Dalton, J. E. P. Santos, J. A. Rodrigues, F. A. Braga, S. Bitente, and R. C. Chebel. 2008. Effect of breeding protocols and reproductive tract score on reproductive performance of dairy heifers and economic outcome of breeding programs. J. Dairy Sci. 91:3424-3438.

Stevenson, J. S., S. M. Tiffany, and M. C. Lucy. 2004. Use of estradiol cypionate as a substitute for $\mathrm{GnRH}$ in protocols for synchronizing ovulation in dairy cattle. J. Dairy Sci. 87:3298-3305.

Vasconcelos, J. L., R. W. Silcox, G. J. Rosa, J. R. Pursley, and M. C. Wiltbank. 1999. Synchronization rate, size of the ovulatory follicle, and pregnancy rate after synchronization of ovulation beginning on different days of the estrous cycle in lactating dairy cows. Theriogenology 52:1067-1078. 